\title{
INTEGRATE HEALTH CARE SYSTEM PERFORMANCE ASSESSMENT FOR VALUE-BASED HEALTH CARE IMPLEMENTATION IN LATVIA
}

\author{
*Māra Pētersone ${ }^{1}$, Kārlis Ketners² ${ }^{2}$ Dainis Krieviṇ ${ }^{3}$ \\ ${ }^{1}$ Riga Technical University, Latvia \\ ${ }^{2}$ BA School of Business and Finance, Latvia \\ ${ }^{3}$ Pauls Stradins Clinical University Hospital, Latvia \\ *Corresponding author's email: mara.petersone@rtu.lv
}

\begin{abstract}
Every year, efforts are applied worldwide, particularly in the European Union, to improve health care systems by increasing the added value of resources already available for health care financing by increasing the performance of health care systems. According to experts of the World Health Organisation (WHO) and the Organisation for Economic Cooperation and Development (OECD), 20-40\% of the resources are used for complications that could be avoided, for unnecessary treatment or administrative inefficiency. Therefore, a new initiative to improve health performance - the value-based health care concept (VBHC) is becoming increasingly popular in the world, and particularly in Europe.

This scientific article aims to explore the possibilities of applying VBHC in Latvia and the interaction between various management tools in the field of health care. Application of the VBHC concept in Latvia is offered for discussion, where the outcome of the corresponding measure would be identified for each health service provider as part of a one-patient (care) pathway involving several independent health service providers. Based on the Health Care System Performance Assessment (HSPA), clinical (patient) pathways and indicators, to initiate an integrated VBHC model in four priority areas: circulatory system diseases, oncology, mental health, maternal and child health.

Meta-analysis of the research is based on the use of qualitative data sources - the existing data sources from policies implemented by the Ministry of Health in Latvia and examples of the introduction of VBHC initiatives worldwide summarised by the VBHC Center Europe. The deductive research is based on the Value-Based Healthcare concept introduced by Porter and Teisberg (2007).
\end{abstract}

Key words: Health System Performance Assessment; VBHC; Health policy, Patient pathway; Scorecards; Outcome Measures.

\section{Introduction}

Every year, efforts are applied worldwide, particularly in the European Union, to improve health care systems by increasing the added value of resources already available for health care financing, by increasing the performance of health care systems. This issue is relevant for Latvia, where financing allocated to the health sector from the general government-subsidised sectors is one of the lowest among the OECD countries (4.03\% of GDP in 2018, $3.53 \%$ in $2017,3.73 \%$ in $2016,3.75 \%$ in 2015 , $3.80 \%$ in 2014) (Pētersone, Ketners, \& Erinšs, 2019; OECD, 2020), due to the need to ensure the efficient functioning of the system within the limited resources.

According to experts of the World Health Organisation (WHO) and the Organisation for Economic Cooperation and Development (OECD), $20-40 \%$ of the resources are used for complications that could be avoided, for unnecessary treatment or administrative inefficiency (OECD, 2017). There of a new initiative to improve health performance - the value-based health care concept (VBHC) is becoming increasingly popular in the world, and particularly in Europe. Several bright examples of using the value-based health care concept can be mentioned. Martini Klinik (Hamburg, Germany) for the treatment of prostate cancer (Porter, Deerberg - Wittram, \& Feeley, 2019). The Karolinska University Hospital
(Stockholm, Sweden) reorganised its structure from the classical departments into 270 integrated practice units (IPUs). Netherlands - outcomes of cardiac interventions are collected in a nationwide initiative (Meetbaar Beter). Diabeter (Netherlands) Dutchcertified clinic network that specialises in providing comprehensive and individualised care for children and young adults with type 1 diabetes (DeerbergWittramand \& Lüdtke, 2016). Boston Children's Hospital (BCH) (USA) aimed to be a worldwide leader in improving children's health through the provision of high-quality care, cutting-edge research, teaching and local community outreach (Kaplan, Witkowski, \& Hohman, 2012). French ophthalmic centres -Institut Ophtalmologique Sourdille Atlantique, University Hospital in Nantes and Chénieux Ophtalmologie at Polyclinique de Limoges - have recently adopted the standard set for cataract surgery developed by the International Consortium for Health Outcomes Measurement (ICHOM).

Latvian scientists, policymakers and practitioners have also expressed interest in value-based health care and all benefits that such an initiative can provide. Thus, Barzdiņš et al. (2019), having analysed the treatment of myocardial infarction (AMI) in Latvia by using administrative data, have concluded that the results obtained from the research confirm that the quality and results of AMI treatment in entire Latvia 


\section{Non-financial Targets}

\begin{tabular}{|c|c|c|}
\hline Sub-target & Performance indicators & Dimensions \\
\hline \multirow{4}{*}{$\begin{array}{l}\text { Service } \\
\text { availability }\end{array}$} & Ratio of number of practitioners and nurses & input \\
\hline & Total number of patients in hospital/outpatient & output \\
\hline & Number of beds in a medical institution & input \\
\hline & Average waiting time to receive a consultation from an outpatient specialist & process \\
\hline \multirow{5}{*}{$\begin{array}{l}\text { Efficiency of } \\
\text { services }\end{array}$} & Average duration of treatment in a hospital & process \\
\hline & Average loading of beds in a $24 \mathrm{~h}$ in-patient clinic & output \\
\hline & Average load of $\mathrm{CT}$ and magnetic resonance equipment & output \\
\hline & Share of functional specialists from all employees & input \\
\hline & $\begin{array}{l}\text { Proportion of working medical practitioners in the age group } 25-40 \text { from the total } \\
\text { number of medical practitioners }\end{array}$ & input \\
\hline \multirow{4}{*}{$\begin{array}{l}\text { Quality of } \\
\text { services }\end{array}$} & Patient mortality rate, number and proportion & outcome \\
\hline & Number of complications & outcome \\
\hline & $\begin{array}{l}\text { Proportion of medical practitioners working overtime during the period } \\
\text { considered }\end{array}$ & input \\
\hline & $\begin{array}{l}\text { Volume of patients released home who were re-hospitalised on the same or next } \\
\text { day }\end{array}$ & outcome \\
\hline \multirow{2}{*}{$\begin{array}{l}\text { Knowledge } \\
\text { transfer }\end{array}$} & Independent research activities & output \\
\hline & $\begin{array}{l}\text { Students education and professional development process of practitioners and } \\
\text { medical support persons }\end{array}$ & output \\
\hline
\end{tabular}

(Barzdins et al., 2019) should be improved by taking concrete measures. In the context of structural reforms, a number of projects financed by the European Structural Fund have been implemented - Health Care System Performance Assessment (Baltāne, 2018), "Development and Introduction of Guidelines for the Health Care Networks Development and Quality Assurance Systems within the Priority Health Care Areas", "Establishment of a Public Monitoring System for the Quality and Efficiency of Health Care".

However, the assessment of different aspects of health care sector alone does not create a mechanism for improving the functioning of all parties involved in the health system, particularly at the level of clinical university hospitals.

This scientific article aims to explore the possibilities of applying VBHC in Latvia and the interaction between various management tools in the field of health care.

The main idea of the research is to arise discussions on VBHC valuables among scientists, policy makers, non-governmental organisations, doctors' associations and health services providers in Latvia regarding who should step with an initiative and how the VBHC interpretation in Latvia should look like conceptually.

Porter and Teisberg (2007) introduced the valuebased healthcare concept as a reform strategy for health care systems, which is market-based but conducted by doctors. "The right kind of competition - competition to improve results-will drive dramatic improvement" (Porter \& Teisberg, 2007; Porter \& Lee, 2013; Porter, 2010). Still, Vainieri et al. (2020) took a holistic view regarding the value-based concept, which means a less individually-focused approach (patient-centred), as initially claimed by Porter (2010), and a more socially inclusive perspective that considers, for instance, equity aspects. When discussing the integration of VBHC into the Latvian health care system, a holistic approach of the concept should be discussed, focusing on shifting the focus of attention from the volume of services (output) to the value or results achieved (outcome) within all levels of health service providers, emphasising that the value is not measured according to the health care process used (process). Still, measuring and improving is an important tactic, but it cannot replace the determining of results and costs. Table 1 summarises non-financial targets, according to which state companies of the Latvian health care sector assess their operation (CrossSectoral Coordination Centre, 2018).

As we see from Table 1, regarding non-financial targets, the volume of services is mostly assessed at state companies in Latvia, and only in certain cases the service value. When evaluating activities of hospitals, Table 1 reflects a number of performance aspects, but these indicators do not reflect personal value, technical value, allocative value and public value in the VBHC 
context (EC, 2019), whereas strategic financial objectives are in compliance with the principles of good management of public companies.

\section{Materials and Methods}

As the research method, meta-analysis based on the use of qualitative data has been chosen - the existing data sources from policies implemented by the Ministry of Health in Latvia and examples of the introduction of VBHC initiatives worldwide summarised by the VBHC Center Europe. The deductive research is based on the Value-Based Healthcare concept introduced by Porter and Teisberg (2007).

Based on qualitative data, conclusions have been reached and a pragmatic approach has been proposed to systematically assess the performed activities, the application of specific policies and the implementation strategy for assessing and developing the performance of the health care system in Latvia, combined in an integrated initiative to implement the value-based health care concept.

"Assessment of the performance of health care systems is a valuable factual material that helps in policy-making. It can also be seen by healthcare providers as a strategic framework for monitoring progress and evaluating best practices by linking health indicators to the health system strategy and functions" (EC, 2020). Health Systems Performance Assessment (HSPA) has established a set of indicators that describe the following health care dimensions:

- resources (input) (finances, human resources and other provision);

- process (process) (e.g., accessibility, quality, safety);

- short-term result (outcome) (e.g., received care, mortality);

- long-term result (outcome) (e.g., survival).

Noto et al. (2019) built upon the Donabedian conceptual model, the HSPA framework for Latvia has been characterised by four main domains, which are Structures, Processes and Outcomes, organised in multiple key dimensions, namely, Financial Resources, Human Resources and Equipment (Structures), Efficiency, Quality, Safety, Prevention, Demand Management, Equity, Accessibility and Health Status (Processes and Outcomes). Due to the lack of available data, the Patient Experience domain has not been populated by indicators yet. HSPA have been identified within the domains of Processes and Outcomes. At present, the framework consists of the overall number of 191 indicators classified in the domains, dimensions and pathways as portrayed (Noto el al., 2019), i.e. 23 structure indicators, 80 process indicators and 88 outcome indicators.

HSPA provides benchmarking of indicators in Latvia. Depending on the indicator, the assessment is performed at the international, regional, local and health service providers' level. The indicators (performance) generally focus on four priority areas: circulatory system diseases, oncology, mental health, maternal and child health. The framework foresees the benchmarking of indicators (performance) (Lepiksone, 2019), which have an informative nature at the level of health service providers.

In addition, in these four priority areas of the project co-financed by the European Social Fund, to implement "the development and implementation of guidelines for the development of health care networks and quality assurance systems within the framework of priority health care areas", clinical guidelines and the relevant clinical algorithms, clinical (patient) pathways and indicators for the four priority areas have been identified. In order to improve the quality of the patient health care, 115 clinical algorithms and 92 clinical patient pathways will be developed over the coming years (SPKC, 2010).

A management mechanism is missing where each independent health service provider is responsible for its service and, at the same time, would be interested in achieving the overall outcome. All health systems face similar challenges. The European Union Member States are introducing Value-Based Health Care (VBHC) to improve individual health conditions.

The European Institute of Innovation and Technology (EIT), in its "Handbook for Pioneers Implementing Value-Based Health Care in Europe", has developed the VBHC implementation matrix. The implementation matrix is based on six dimensions and nine matrix elements: Condition, Partnering (External Collaboration and Internal Forces), Comparing, Rewarding (Investments and Incentives), Improving, Recording (Data platform and Scorecard).

Scorecard defines processes, costs and outcome indicators while applying case-mix adjustment. The scorecard aims to measure the value of care for a specific condition, by incorporating a minimal set of process, outcome and cost indicators. Process measures how care was delivered. Outcomes measure the impact on patient health status. Costs measure the money spent to achieve these outcomes. Combined, these three metrics track changes to detect variation over improvement cycles (EIT Health, 2010).

According to their structure, the clinical (patient) pathways and corresponding indicators, which are developed in Latvia in the context of the reforms, correspond to the scorecard aims defined by "Handbook for Pioneers - Implementing Value-Based Health Care in Europe".

\section{Results and Discussion}

Conceptually, VBHC makes it possible to function at the level of the health care system (Pētersone, 


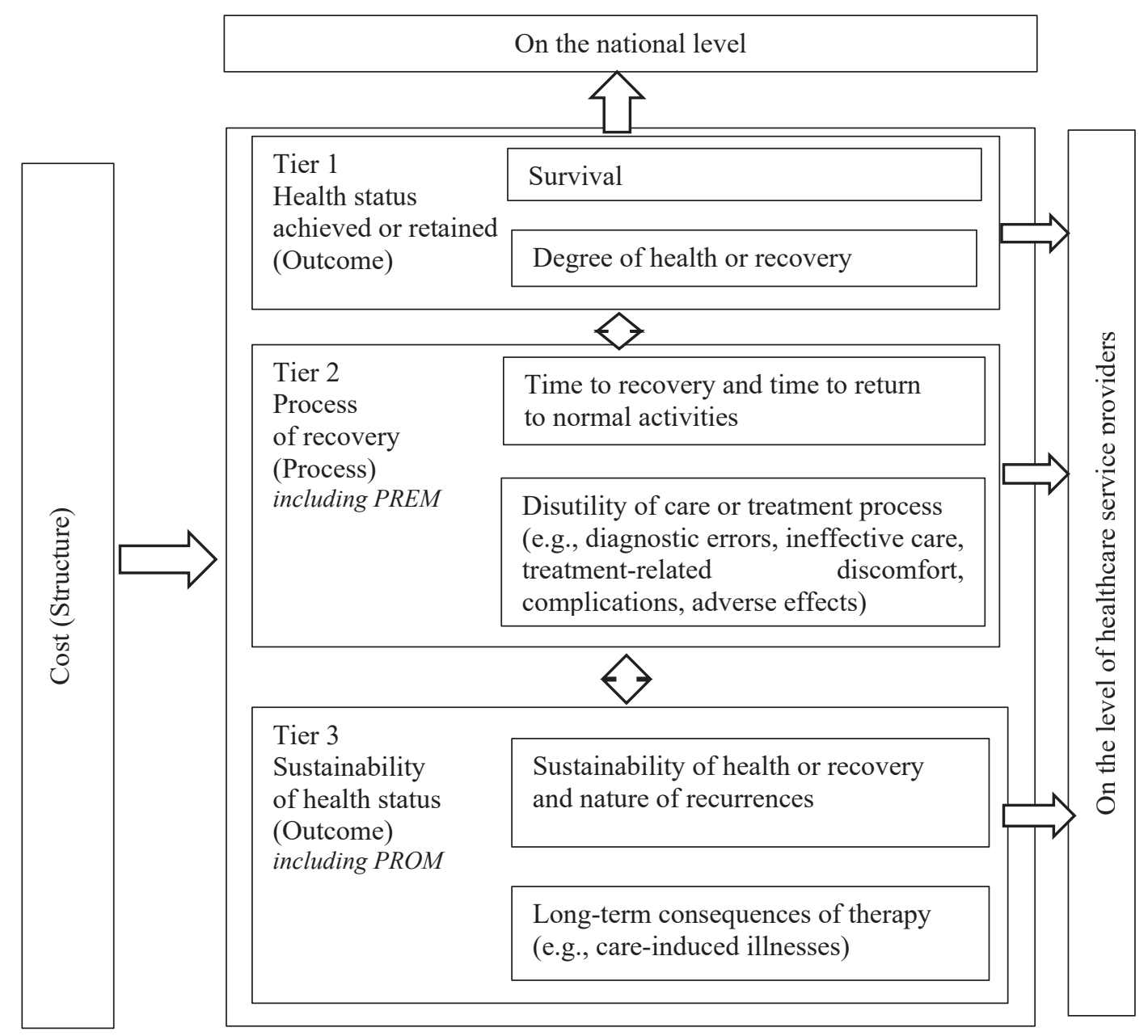

Figure 1. The Outcome Measures Hierarchy (developed by the authors based on Porter 2010).

Ketners, \& Erins, 2020), whereas in Europe it is mainly used at the level of health care providers (VBHC Europe, 2020). Taking into account the Latvian health care financing model, population and the special features of the health services management systems (Pētersons et al., 2019), the authors offer the discussion on the application of the VBHC concept in Latvia at the level of the health care system, where, within the framework of one patient's (care) pathway, with involvement of several independent health service providers, the outcome of the corresponding measures would be identified for each health service provider. Based on existing HSPA, clinical (patient) pathways and indicators should initiate an integrated VBHC model in four priority areas: circulatory system diseases, oncology, mental health, maternal and child health. It is necessary to complement the VBHC model with missing indicators to better reflect the VBHC model in Latvia. In addition, it is proposed to create a cascade of indicators based on the Outcome Measures Hierarchy by Porter (2010) (Figure 1).

In line with Porter (2010), the VBHC Outcome Measures Hierarchy can be recommended for Latvian circumstances, which provides three assessment levels for the system. Tier 1 is the health status that is achieved or retained (Survival and Degree of health or recovery). Tier 2 outcomes are related to the recovery process (Time to recovery and time to return to normal activities and Disutility of care or treatment process (e.g., diagnostic errors, ineffective care, treatmentrelated discomfort, complications, adverse effects)). Next Tier 3 is the sustainability of health status, which can be divided into two sub-levels: Sustainability of health or recovery and nature of recurrences and Long-term consequences of therapy (e.g., careinduced illnesses).

The cascading of indicators is essential for the inclusion of health indicators identified in the national planning documents to the strategic planning documents of health service providers, as individual indicators can be traceable at regional and municipal level. The strategy and the strategic action plan of the health service provider should be based on VBHC indicators (outcome and process) when defining objectives, tasks, performance results and indicators and numerical values. Currently, a group of analytical 
indicators for the performance measurement system is focused on the performance analysis and improvement of the organisational volume indicators. The traceability of performance and interconnectedness of various organisational units of the health service provider would help in management of the operational process.

VBHC offer a complex mechanism of management, e.g. the VBHC Implementation Matrix, where one of the elements is Scorecard. HSPA and the outcome, process and structure indicators of the clinical (patient) pathway conforms in their structure to the Porter's Outcome Measures Hierarchy.

In the strategic purchasing context, the outcome and process indicators of the health service providers can be one of the Criteria for Section of a Health Care Facility and Signing of a Mid-Term Contract on Heath Service Provision (Pētersone et al., 2020; Van Veghel et al., 2018).

The health service providers are starting to collect parameters for Patient Reported Experience Measures (PREMs) (Slawomirski et al., 2018) increasingly more often. Latvian Clinical University hospitals have started collecting data from PREMs, as well as have been involved in the project financed by the European Structural Fund for the development and implementation of the PREMs system. Although PREMs are not classified as a health outcome measure, rather as a process measure, such information is an important source in improving the management of hospital processes that will allow to improve care in line with expectations of patients.

Patient reported outcome measures (PROMs) are longitudinally collected to measure effectiveness within clinical trials or for improving individual patients' health status by means of his or her reported functional, psychological and social outcomes (Van Der Wees et al., 2014). PROMs data are not collected in Latvia; however, it is an innovative policy also in Europe (Pennucci, Rosis, \& Passino, 2020). The PaRIS survey fills a critical information gap in primary care, focusing on PREMS and PROMS. The Patient-reported Indicator Surveys (PaRIS) initiative of the Organisation for Economic Cooperation and Development (OECD) is currently in its design phase (OECD, 2020).

The most complicated and contentious issue is and remains cost accounting and accounting per one patient. Within the framework of the values, the corresponding total costs are used in the single patient's full cycle of care. Costs per patient are a hard-to-measure indicator for a number of reasons, mainly because hospital cost accounting systems are departments, not patients, and they are intended for settlements for transactions payable under payper-service contracts. Large health service providers who want to introduce VBHC to justify a cost per patient are recommended to use the Time-Driven Activity-Based Costing (TDABC). (Beck da Silva Etges, Polanczyk, \& Urman, 2020; Cidav et al., 2020) TDABC, just as the VBHC initiative is based on scorecard identification (Keel et al., 2017).

\section{Conclusions}

By showing their own initiative, leading health service providers in Europe are increasingly introducing a value-based healthcare concept (VBHC) into their work organisation.

Conceptually, VBHC provides for the possibility of functioning at the healthcare system level; however, it is mainly used at the level of healthcare providers in Europe.

Just setting of the indicators benchmarks in Latvia does not create a mechanism to improve the functioning of the health system, particularly at the level of Clinical University hospitals. A management mechanism is missing where each independent health service provider is responsible for its service and, at the same time, would be interested in achieving the overall outcome.

The cascading of indicators is essential for the inclusion of health indicators identified in the national planning documents into the strategic planning documents of health service providers, as individual indicators can be traceable at the regional and municipal level.

Large health service providers who want to introduce VBHC to justify a cost per patient are recommended to use the Time-Driven Activity-Based Costing (TDABC).

\section{Acknowledgements}

This work has been supported by the European Regional Development Fund within the Activity 1.1.1.2 "Post-doctoral Research Aid" of the Specific Aid Objective 1.1.1 "To increase the research and innovative capacity of scientific institutions of Latvia and the ability to attract external financing, investing in human resources and infrastructure" of the Operational Programme "Growth and Employment" (No.1.1.1.2/VIAA/2/18/330).

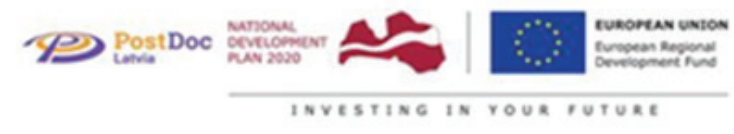

\section{References}

Baltāne, Z. (2018). Datu bāzes izmantošanas piemēri veselības aprūpes kvalitātes rādītāju aprēḳināšanā (Examples of using the database in calculating health care quality indicators). Retrieved November 21, 2020, from http://med.oranzais.lumii.lv/Konference/Baltane_3.06.2018.pdf. (in Latvian). 
Barzdins, J., Luguzis, A., Valeinis, J., Lepiksone, J., Skrule, J., Pildava, S., \& Konstante, R. (2019). Towards evidence-based management: A nationwide administrative data-based audit of acute myocardial infarction in Latvia. International Journal of Healthcare Management. DOI: 10.1080/20479700.2019.1693710.

Cidav, Z., Mandell, D., \& Pyne, J. (2020). A pragmatic method for costing implementation strategies using time-driven activity-based costing. Implementation Sci 15, 28 DOI: 10.1186/s13012-020-00993-1.

Deerberg-Wittram, J., \& Lüdtke, L. (2016). Diabeter value-based health care delivery in diabetes diabeter: value-based health care delivery in diabetes. The Boston Consulting Group, September 2016.

EIT Health (2020). Implementing Value-Based Health Care in Europe: Handbook for Pioneers. Retrieved December 11, 2020, from https://eithealth.eu/wp-content/uploads/2020/05/Implementing-Value-BasedHealthcare-In-Europe_web-4.pdf.

EK (2019). Defining value in "Value-based healthcare". Report of the Expert Panel on effective ways of investing in Health (EXPH). DOI: 10.2875/872343.

EK (2020). Health systems performance assessment. Retrieved December 1, 2020, from https://ec.europa.eu/ health/systems_performance_assessment/overview_lv.

Etges, A.P.B.dS., Polanczyk, C.A., \& Urman, R.D. (2020). A sstandardised framework to evaluate the quality of studies using TDABC in healthcare: The TDABC in Healthcare Consortium Consensus Statement. Research Square; DOI: 10.21203/rs.3.rs-33107/v3.

Kaplan, R.S., Witkowski, M.L., \& Hohman, J.A. (2012). Boston Children's Hospital: Measuring Patient Costs. Harvard Business School Case 112-086, March 2012.

Keel, G., Savage, C., Rafiq, M., \& Mazzocato, P. (2017). Time-driven activity-based costing in health care: A systematic review of the literature. Health Policy, Vol. 121 (7) 755-763. Retrieved December 11, 2020, from https://www.sciencedirect.com/science/article/pii/S0168851017301240.

Lepiksone, J. (2019). Veselības sistēmas snieguma novērtēšanas ietvars, tajā iekḷautie rādītāji pakalpojumu sniedzēj līmenī (Health system performance evaluation framework, indicators included at the level of the service provider). Retrieved November 22, 2020, from https:/www.spkc.gov.lv/sites/spkc/files/data content/2_hspa_indikatori_j_lepiksone_181020191.pdf. (in Latvian).

Noto, G., Corazza, I., Kḷavina, K., Lepiksone, J., \& Nuti, S. (2019). Health system performance assessment in small countries: The case study of Latvia. Int J Health Plann Manage. 2019 Oct, 34(4): 1408-1422. DOI: 10.1002/hpm.2803.

OECD (2017). Tackling Wasteful Spending on Health. OECD Publishing, Paris. DOI: 10.1787/9789264266414en.

OECD (2020). Latvia - General Government Spending - Health - \% of GDP. Retrieved November 21, 2020 , from https://knoema.com/DP_LIVE/oecd-data-live-dataset?country=1000990\&indicator $=1001330 \&$ subj ect $=1000420 \&$ measure $=1000510 \&$ frequency $=$ A.

OECD (2020). Patient-reported Indicator Surveys (PaRIS), Retrieved December 11, 2020, from http://www. oecd.org/health/paris/.

Cross-Sectoral Coordination Centre (2018). Annual Report on the state capital and state-owned shares in the $2018^{\text {th }}$. Retrieved November 1, 2020, from http://www.valstskapitals.gov.lv/images/userfiles/Parskats par_valsts_kapitalsabiedribam_un_dalam_2018_gada_atverums\%281\%29.pdf.

Pennucci, F., De Rosis, S., \& Passino, C. (2020). Piloting a web-based systematic collection and reporting of patient-reported outcome measures and patient-reported experience measures in chronic heart failure. BMJ Open 2020;10:e037754. DOI: 10.1136/bmjopen-2020-037754.

Pētersone, M., Ketners, K., \& Eriņš, I. (2019). Health Financing Policy Reform Trends: the Case of Latvia. AD ALTA: Journal of Interdisciplinary Research. 9 (2), 265-271. DOI: 10.33543/0902265271.

Pētersone, M., Ketners, K., \& Eriņš, I. (2020). Forthcoming reform of university hospital financing and possibilities for efficiency improvement in Latvia. In: Economic and Social Development, Morocco, Rabat, 26-27 March 2020 (pp. 193-200). Varazdin, Croatia: Varazdin Development and Entrepreneurship Agenc, 2020, ISSN 1849-7535.

Pētersone, M., Ketners, K., Krieviņš, D., \& Eriņš, I. (2020). Strategic Purchasing and Health System Efficiency: Prospects for Health Sector Reform in Latvia. WSEAS Transactions on Business and Economics, 2020, Vol. 17, 41-50. e-ISSN 2224-2899.

Pētersone, M., Ketners, K., Krieviņš, D., Kreicberga, I., \& Eriņš, I. (2019). Developing A Comprehensive Model for Forthcoming Reforms of University Hospitals. Management Theory and Studies for Rural Business and Infrastructure Development, Vol. 41, (2), 197-212. DOI: 10.15544/mts.2019.17.

Porter, M.E., \& Lee, T.H. (2013). The Strategy That Will Fix Health Care. Harvard Business Review, Retrieved November 1, 2020, from https://hbr.org/2013/10/the-strategy-that-will-fix-health-care. 
Porter, M.E., \& Teisberg, E.O. (2007). How Physicians Can Change the Future of Health Care. JAMA. 297(10), 1103-1111. DOI: 10.1001/jama.297.10.1103.

Porter, M.E. (2010). Ph.D. What Is Value in Health Care? The New England Journal of Medicine, 23 Dec, 2010.

Porter, M.E. (2010). What is value in healthcare. N. Engl. J. Med. 2010, 363, 2477-2481.

Porter, M.E., Deerberg - Wittram, J., \& Feeley, T.W. (2019). Martini Klinik: Prostate Cancer care 2019.

Slawomirski, L., van den Berg, M., Karmakar-Hore, S. (2018). Patient-Reported indicator survey (Paris): aligning practice and policy for better health outcomes. World Medical Journal 2018, 64: 8-13.

SPKC (2010). Slimību profilakses un kontroles dienests, Klīniskie algoritmi un pacientu cel̨i (Disease Prevention and Control Service, Clinical algorithms and patient pathways). Retrieved December 10, 2020, from https://www.spkc.gov.lv/lv/kliniskie-algoritmi-un-pacientu-celi. (in Latvian).

Vainieri, M., Noto, G., Ferre, F., \& Rosella, L.C. (2020). A Performance Management System in Healthcare for All Seasons?. Int. J. Environ. Res. Public Health, 17(15), 5590; DOI: 10.3390/ijerph17155590.

Van Der Wees, P.J., Nijhuis-Van Der Sanden, M.W., Ayanian, J.Z., Black, N., Westert, G.P., \& Schneider, E.C. (2014). Integrating the use of patient-reported outcomes for both clinical practice and performance measurement: views of experts from 3 countries. Milbank Q. 2014 Dec; 92(4): 754-75. DOI: 10.1111/14680009.12091. PMID: 25492603; PMCID: PMC4266175.

Van Veghel, D., Schulz, D.N., van Straten, A.H.M., Simmers, T.A., Lenssen, A., Kuijten-Slegers, L., van Eenennaam, F., Soliman Hamad, M.A., de Mol, B.A., \& Dekker, L.R.C. (2018). Health insurance outcome-based purchasing: The case of hospital contracting for cardiac interventions in the Netherlands. International Journal of Healthcare Management. DOI: 10.1080/20479700.2018.1458177.

VBHC Europe (2020). VBHC Prize 2019, VBHC THINKERS MAGAZINE. Edition, Retrieved December 8, 2020, from https:/www.vbhc.nl/wp-content/uploads/VBHC-Thinkers-Magazine-VBHC-Prize-2019edition-Booklet.pdf. 